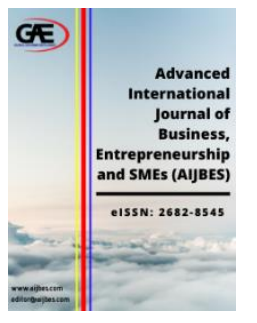

\author{
ADVANCED INTERNATIONAL JOURNAL OF \\ BUSINESS, ENTREPRENEURSHIP AND SMES \\ (AIJBES) \\ WWW.aijbes.com
}

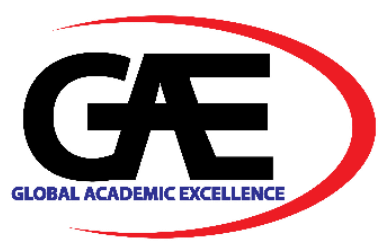

\title{
MILLENNIAL BREAKTHROUGH: THE EAGER TO LIVE A PROSPEROUS FUTURE
}

\author{
Erika Yuono Putri ${ }^{*}$, Sylviana Maya Damayanti ${ }^{2}$
}

1 School of Business and Management, Bandung Institute of Technology, Indonesia

Email: erika_yuono@sbm-itb.ac.id

2 School of Business and Management, Bandung Institute of Technology, Indonesia

Email: sylvianamaya@sbm-itb.ac.id

* Corresponding Author

\section{Article Info:}

\section{Article history:}

Received date: 28.04 .2021

Revised date: 02.05 .2021

Accepted date: 25.05 .2021

Published date: 15.06 .2021

\section{To cite this document:}

Putri, E. Y., \& Damayanti, S. M. (2021). Millennial Breakthrough: The Eager To Live A Prosperous Future. Advanced International Journal of Business, Entrepreneurship and SMEs, 3 (8), 41-59.

DOI: $10.35631 /$ AIJBES.38003.

This work is licensed under CC BY 4.0

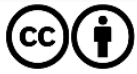

\begin{abstract}
:
The participation of pension funds in Indonesia can be categorized as low which is only 5.48 percent from around 80 million workers, while it also decreased by 5.34 percent from 2018. The average financial literacy index in Indonesia 29.7 percent while the financial literacy in the pension funds sector is just 10.9 percent. Considering that the financial literacy index of pension is still low, awareness regarding retirement planning needs to be developed especially for the younger generation. College students become the strategic target as they have not worked yet and still have enough time to enrich their knowledge regarding retirement planning. Further, the younger generation will also dominate this country's population in 2030-2040. The objective of this research is to define the factors that significantly affect college student's intention to invest in a pension fund. By using logistic regression, this research confirmed that Attitude, Perceived Behavioural Control, and Money Management are the factors that significantly influenced college students' intention to invest in a pension fund. Overall, the study can be used by the government to stimulate social awareness towards retirement planning through pension funds.
\end{abstract}

Keywords:

Retirement Planning, Pension Funds, College Students, Investing Intention

\section{Introduction}

Awareness towards retirement planning has become a raised issue both for the working individual and policy makers (Abd Samad and Mansor, 2013). This issue is being a concern 
Volume 3 Issue 8 (June 2021) PP. 41-59 DOI 10.35631/AIJBES.38003

but not yet being executed by the majority of the individuals as they thought that they still have enough time to consider it later. Retirement planning is not prepared well by both the working individuals and retirees, this has been a raised issue in Malaysia and many other countries (Habib, 2007). People unawareness towards retirement planning will cause a serious problem once they have been retired and get not sufficient income.

People tend to realize about the insufficient funds when they are already facing the reality and do not have enough money to be fully retired as they are being ignorant about pension plans (Shafee, 2018). Retirement is an unfamiliar aspect to be considered when people are in productive age and still having their job. People tend to be concerned about investing to fulfill their daily life and upgrade their lifestyle as they found it more tantalizing. Thus, they forget to consider how to maintain the same standard of living once they do not have the same income as before. Based on Central Bureau of Statistic, Indonesian life expectancy in 2018 is increasing 0.58 point or 0.82 per cent from 2017 and becomes 71.39 years (Badan Pusat Statistik, 2019). With an increase in life expectancy, it will also increase the retirement period thus will increase the requirements of fulfilling the life needs during retirement period (Shafee, 2018).

People tend to get minimum incomes in the retirement period because of the absence of monthly salary or getting a small amount of pension benefit, moreover there are several people who surrender their life to their family. Not to mention that there are several people who still have to finance their kids, which usually comes from educational funds. The effect of the inflation will also cause deficiency if retirees are not being well prepared before. Thus, inadequate retirement planning will result in harm to themselves and their relatives.

In the previous study proposed by Klapper and Panos (2012) the process of retirement planning was described as choices and challenges offering to help people generate the sufficient standard of living after they have been retired. As a sufficient standard of living is subjective, to establish an adequate standard of living after retirement, people have to plan and control their lifestyle since they are still generating money. Thus by making well prepared retirement planning, it will stimulate people to control lifestyle and prepare to live independently after being retired.

In the study proposed by Lusardi and Mitchell (2007), intention about retirement is already determined as the attitudes toward retirement. In order to behave towards retirement planning, people need to build their awareness and have a positive intention about it. Further, the positive intention towards retirement planning will make people aware of investing in pension funds. In Indonesia, the participation of pension funds is still low according to the report of Indonesia Financial Services Authority, in 2019 from around 80 million workers in Indonesia there are only 5.48 per cent of workers who reported joining pension funds. Moreover, the participants of pension fund in Indonesia in 2019 was decreased by 5.34 per cent from to 2018 (Otoritas Jasa Keuangan, 2019).

Based on a survey in 2016 done by Indonesia Financial Services Authority, the pension funds contribution is only 3 per cent from the monthly salary compared to Malaysia which is 12 per cent. Looking into those data, Indonesia's pension fund contribution can be categorized as very low. The retirees welfare in Indonesia is also lower than Malaysia or other countries whose people are more aware of saving for retirement (OJK, 2019). HelpAge International reported that 85.8 per cent of elderly in Indonesia do not get any pension benefit (Tempo.Co, 2018). 


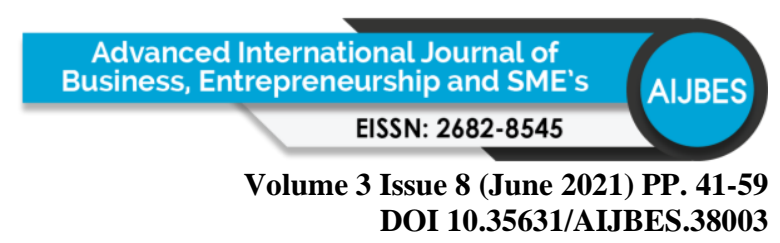

Thus, in order to pursue financial wellbeing and live independently after being retired, people need to be well literate regarding pension funds. Actually, the government of Indonesia has paid their attention towards pension funds, it is poured into discourse on changing of Law Number 11 of 1992 concerning pension fund "Undang-Undang No. 11 Tahun 1992 tentang Dana Pensiun" The changes will be beneficial for the retirees as it will increase the percentage of pension benefits from 75 per cent from the main salary into full salary (Katadata, 2020).

In Indonesia, the average financial literacy index is at the level of 29.7 per cent while the financial literacy in the pension funds sector is just 10.9 per cent which is categorized as low compared to banking (OJK-RI, 2017). Considering that the financial literacy index of pension funds in Indonesia is still low, the knowledge regarding pension fund needs to be developed through some literatures. Having a positive attitude towards retirement planning is needed from the earlier age which can be started intensively since people are pursuing college. Students who come from Diplomas and Undergraduate are dominated by people who have not worked, thus they still have enough time to enrich their knowledge regarding retirement plans. So as they become a worker, they will be clear about preparing funds both for daily life and the retirement period. Students from those degrees are also in the productive age to be able to plan and execute their plan appropriately.

From the social perspective, college students are also considered capable of educating society especially their surrounding environment including their parents (Merdeka, 2020). With qualified knowledge and smart strategies, college students are able to move and make changes to help the government to increase financial literacy and inclusion mainly in the pension fund sector. In 2019, Indonesia Financial Services Authority also published a book for higher education regarding pension plan named "Buku-6 Program Pensiun Seri Literasi Keuangan Perguruan Tinggi.". This program shows that the government of Indonesia also has a great expectation towards college students to create a prosperous Indonesian society.

However, so far college students thought that retirement planning was too far to be prepared as they do not have independent incomes. Thus, they indirectly reject the knowledge regarding retirement planning and hold themselves to be financially literate. In the previous study proposed by Boon, Yee and Ting (2011), younger people tend to have little savings and delay to plan for savings as they still have a lot of time to take the action later. They also do not have a clear intention whether the savings will support them to have the same standard of living as before once they have been retired. Late retirement planning will cause serious retirement gap problems as the decrease of income and the strong desire to have the same standard of living as before.

Retirement planning has a close relation with future plan perspective on which will make an individual start to think about the targeted goals followed by the process of achieving it (Moorthy, K., Chelliah, T.D., Sien, C.S., Leon, L C., Kai, N.Z., Rhu, W.C. and Teng, 2012). According to Hershey and Mowen (2000), retirement planning behavior is having a significant relation to the targeted goals that have been clearly stated before and the attitude towards retirement planning. Thus, as college students are unaware of their future life after being retired, the behavior of having a planned savings and controlled lifestyle will also be ruled out.

In this case, the development of pension funds awareness in the younger generations will be potential as the demographic structure of Indonesia will be dominated by a productive age Copyright $\odot$ GLOBAL ACADEMIC EXCELLENCE (M) SDN BHD - All rights reserved 
Volume 3 Issue 8 (June 2021) PP. 41-59 DOI 10.35631/AIJBES.38003

society in the next decade. Now statistically, the population of the younger generation in Indonesia is on 33 per cent until 34 per cent from the total population, it is predicted that the younger generation will be dominated as the decreasing baby boomer and generation $\mathrm{X}$ population (Kontan, 2017). The occurrence of demography bonus which reached 297 million inhabitants or 64 per cent of the total population in 2030-2040 also clarified the productive age domination (Afandi, 2017). Thus, the younger generation will be the main target market for pension funds for decades.

Although financial literacy in Indonesia is still categorized as low, but the level of financial literacy in East Java is beyond average on the level of 35.6 per cent (OJK-RI, 2017). Which means that East Java was successfully implementing financial literacy in the community. Besides financial literacy, the financial inclusion in East Java is also beyond average on the level of 73.2 per cent compared to the country average which is 67.8 per cent. Although the financial literacy and inclusion in East Java can be categorized as high but the public preferences towards pension funds is very low. Hence, we can simply conclude that East Java financial literacy and inclusion are dominated by things other than pension fund or retirement planning. As stated on Indonesia National Strategic of Financial Literacy 2017 "Strategi Nasional Literasi Keuangan Indonesia 2017" that there is a positive relationship between financial literacy and financial inclusion, thus we can predict that the low level of pension funds preference in East Java is caused by the minimum knowledge towards retirement planning and pension funds.

Indonesia Financial Services Authority of East Java also held Literacy and Inclusion Training "Pelatihan Literasi dan Inklusi (PETIK)" in East Java which cooperated with Regional Financial Service Institution Communication Forum and Airlangga University on September 2019. The training was followed by college students both from the public (PTN) or private (PTS) universities in East Java in order to increase the society's financial literacy and financial inclusion to create East Java Well Finance Literate. Besides UNAIR, they also cooperated with other 4 universities in East Java. Thus, Indonesia Financial Services Authority of East Java expected that college students could convey their knowledge about financial services industry to society as they have high intellectuality and idealism (UNAIR News, 2019).

The objective of this research is to define the factors that significantly affect college student's intention to invest in a pension fund. As college students were expected to bring an impact to society, they were supposed to have a great understanding towards retirement planning. Likewise, it will be of benefit to their own future once they have been worked, thus they will be ready and aware to allocate funds in order to have a similar standard of living after being retired. As it already stated before that East Java was having a low preference regarding pension funds although they have a higher financial literacy level compared to the country's financial literacy level. As the factors may be varied, this research will focus on several factors which have already been tested by previous study in Italy (Bongini and Cucinelli, 2019). There are several factors including Attitude, Subjective Norms, Perceived Behavioural Control which covered in Theory of Planned Behaviour proposed by (Ajzen, 1991), Financial Pension Knowledge, Financial Literacy, and Money Management. To get the data, this survey is conducted in several universities in East Java. The respondent will be both new entrants (batch 2020) and enrolled students (batch 2017, 2018 and 2019) both from Diploma and Undergraduate programs from those universities. 
Volume 3 Issue 8 (June 2021) PP. 41-59

DOI 10.35631/AIJBES.38003

To the best of our knowledge, there is no previous study focusing on college student's intention to invest in a pension fund in Indonesia. Majority of the previous study regarding pension funds in Indonesia talked about system and accountant principles (Hayuningtyas Pramesti Dewi, SE., Ak., M.Ak. and Lestari, 2016; Ngumar, 2016). As college students were expected to bring an impact to society, thus they were supposed to have a great understanding towards retirement planning. Likewise, it will be of benefit to their own future once they have been worked, thus they will be ready and aware to allocate funds in order to have a similar standard of living after being retired. Finally, the factors that have been researched can be used by the government to stimulate society awareness towards retirement planning through pension funds which lead to increasing the retirees' welfare.

\section{Literature Review}

\section{Retirement Planning}

There are several things that may change as an effect of increasing life expectancy and retirement planning is the one that people start concerning (Ibrahim, Isa and Ali, 2012). As future life becomes one of the people's considerations to get enough income when they are still working, retirement planning takes an important role to realize those dreams. Based on study in Malaysia, even several employees have had Employee Provident Fund (EPF) but the nominal is still insufficient to fulfill the need for having sustainable life after retirement, which this should be considered to have a well prepared retirement planning (Mohidin et al., 2013). Those facts make us realize that there is a risk that may appear in the future life and individuals are having an urge to make retirement decisions (OECD, 2016). Thus the intention of retirement needs to be known and understood earlier when individuals still have enough time and qualified resources to give a maximum effort to prepare their life after retirement (Shafee, 2018)

Even though retirement planning delay will result in a bad future and can be a lot more expensive. People tend to realize about the insufficient funds when they are already facing the reality and do not have enough money to be fully retired as they are being ignorant about pension plans (Shafee, 2018). Retirement planning is not prepared well by both the working individuals and retirees, this has been a raised issue in Malaysia and many other countries (Habib, 2007). In order to fulfill the same standard of living when people have retired, they should be set aside a part of their monthly income when they are still productively working (Subha and Shanmugha, 2014)

As proposed by Lusardi and Mitchell (2009), people need to care and engage with money and those instruments at a youthful age. Applied regression model has successfully tested that financial literacy positively influenced individual's retirement planning behavior (Hassan et $a l ., 2016)$. Raising financial literacy is the fundamental rule to manifest an effective way of retirement planning especially for those who are facing a hard financial pressure (Lusardi and Mitchell, 2011). In order to stay competitive against uncertain conditions related to the economic and financial sector, people need to balance between 'now' conditions and also consider the future that is more unpredictable, to make sure that they will have a decent future (Shafee, 2018). 


\section{TPB Factors}

Theory of Planned Behaviour explained about guidance of a model of human behavior which stated that "intention are determined by three constructs : attitude (ATT) towards the behavior, subjective norms (SN) and perceived behavioural PBC)" (Ajzen, 1991, 2002). TPB is the theoretical framework to measure the intention to invest in some financial instruments including pension fund (Bongini and Cucinelli, 2019). "Intention (I) are assumed to capture the motivational factors that influence a behavior and to indicate how hard people are willing to try or how much effort they would exert to perform a behaviour" (Ajzen, 1991). Regarding the Attitude (A), Davis and Hustvedt (2012) assumes that an individual attitude towards a certain behaviour positively influence the intention to save for retirement. In the context of financial aspects, subjective norms $(S N)$ defined as if the family and relatives are willing to buy or already use pension funds, the college student will also have a willingness and intend to hold a pension fund (Bongini and Cucinelli, 2019). Perceived control behaviour (PBC) as confirmed by Nosi et al., (2017) that it has a relevancy on the intention to buy long term investment which in this case is pension fund.

\section{Financial Literacy}

In order to be financially prepared for life after retirement, financial literacy and self-education are being the important factors which will affect people ability to manage and plan their retirement (Shafee, 2018). In this case, "FL is positively related to retirement savings" (Lusardi and Mitchelli, 2007; Crossan, Feslier and Hurnard, 2011; Lusardi and Mitchell, 2011; Sekita, 2011; van Rooij, Lusardi and Alessie, 2012; Agnew, Bateman and Thorp, 2013; CastroGonzales, 2014; Fornero, 2015; Boisclair, Lusardi and Michaud, 2017; Ricci and Caratelli, 2017)

\section{Financial Pension Knowledge}

Based on the study proposed by Chan and Stevens (2008) individuals' level of pension literacy affects the decision of choosing a retirement plan. People who have a good knowledge regarding pension plans tend to have additional savings. The researcher also proposed that pension knowledge influences people's pension savings (Landerretche and Martínez, 2013)

\section{Money Management}

Some studies stated that individuals who get pocket money more likely have savings than the one who do not receive (Furnham, 1999; Furnham and Kirkcaldy, 2000; Lewis and Scott, 2000; Kirkcaldy, Furnham and Martin, 2003). Savings is important to pursue a well financing life, on which including savings for retirement, savings for properties and emergency funds (Bucciol and Veronesi, 2014). 


\section{Hypothesis Development}

DOI 10.35631/AIJBES.38003

\section{Figure 1: Research Framework}

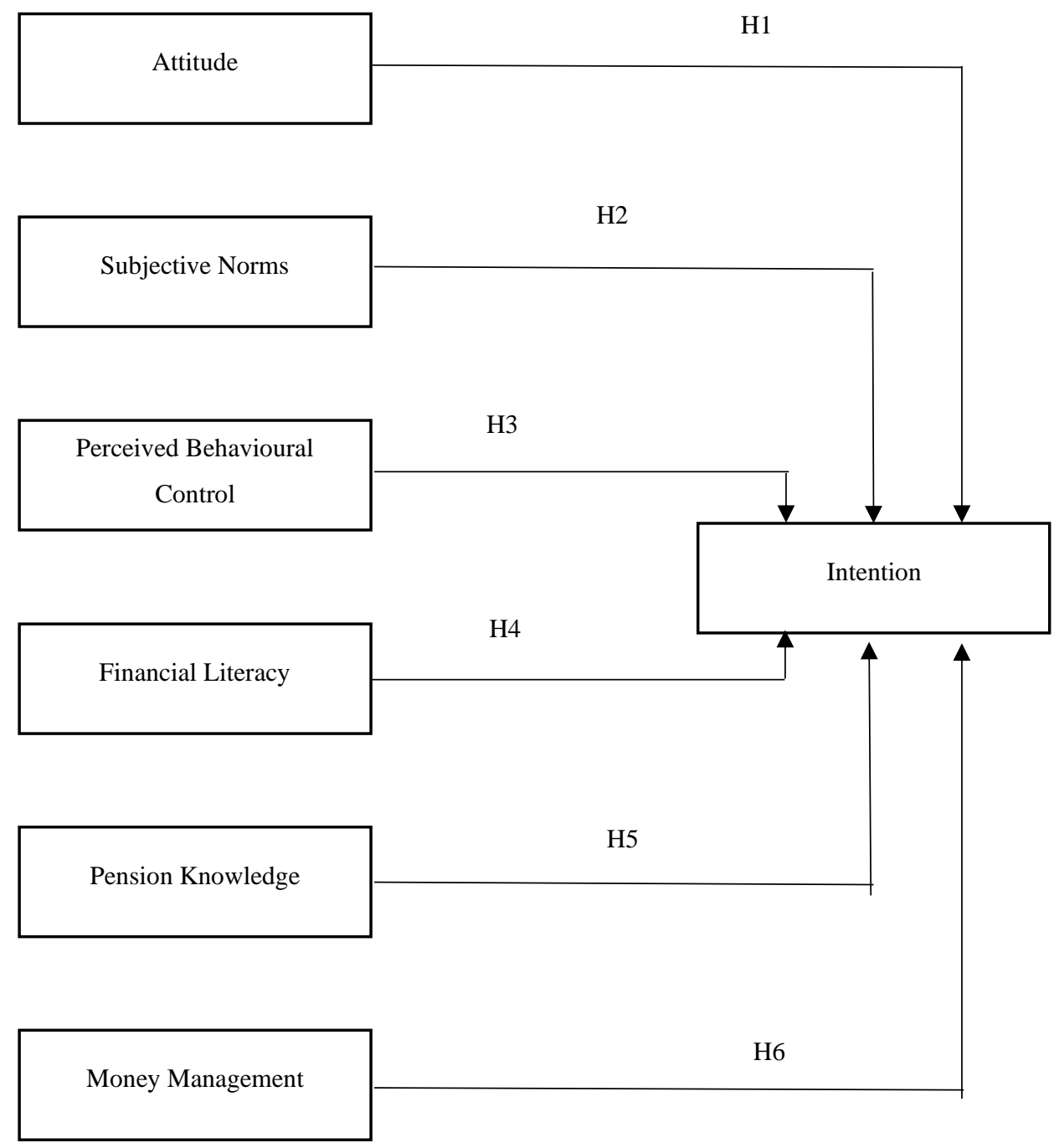

H1: Attitude significantly influence college students' intention to invest in a pension fund.

$\mathrm{H} 2$ : Subjective norms significantly influence college students' intention to invest in a pension fund.

H3: Perceived behavioural control significantly influence college students' intention to invest in a pension fund.

H4: A higher of Financial Literacy significantly influence college students' intention to invest in a pension fund.

H5: A higher of Pension Knowledge significantly influence college students' intention to invest in a pension fund.

H6: Money management significantly influence college students' intention to invest in a pension fund. 


\section{Methodology}

\section{Population}

The target respondent of this research will be the population of college students in East Java for both new entrants and enrolled students from Diploma and Undergraduate programs. The total number of population based on Indonesian Higher Education Statistical Year Book 2018 is 587,288 (Dikti, 2018).

\section{Sample}

The researcher calculated the sample size calculated using Slovin formula. The formula is as follows:

Where,

$\mathrm{n}=$ sample size

$$
n=\frac{N}{1+N(e)^{2}}
$$

$\mathrm{N}=$ population size

$\mathrm{e}=$ level of precision

Based on this formula the calculation of sample size will be :

$$
\begin{aligned}
& \mathrm{n}=\frac{587,288}{\left(1+587,288 * 0.05^{2}\right)} \\
& \mathrm{n}=399.72
\end{aligned}
$$

In this research, the researchers used 95 per cent level of confidence and 5 per cent margin of error as it is generally accepted for statistical measurements and the most commonly used confidence interval for many literatures (Šimundić, 2008). Based on the given formula, the number of respondents needed to be addressed is 400 respondents.

\section{Validity and Reliability Test}

Validity and reliability tests are the prior tests before distributing the questionnaire to the whole sample. Validity test is made to test the extent to which a measurement tool measures what it asserts to measure, while Reliability test is the measurement whether of that certain tools will generate in consistent results and equal values (Blumberg, B. F., Cooper, D. R., \& Schindler, 2014). For validity tests, this research will use Pearson Correlation for the interval data and content validity for nominal data. The Pearson correlation will be valid if $r$ count $>r$ table. For the reliability test, this research will use Cronbach Alpha, the score of the Cronbach Alpha should be $>0.60$ as it can be categorized as good. These tests will show the result whether the questionnaires are valid and reliable to be applied for the whole sample.

\section{Data Collection}

This research uses primary data which collected using online questionnaires in the November 2020. The questionnaire is used to get the real picture of the college student's condition in order to ensure the factors that might influence their intention to invest in a pension fund. The questionnaires are divided into four main sections which are TPB factors, financial literacy, financial pension knowledge and money management.

\section{Research Model}

Logistic regression will be used as an appropriate regression analysis for binary dependent variables with nominal and interval independent variables. Logistic Regression will be used to examine the relationship between the independent variables which are the TPB factors (ATT, SN, PBC), Financial Literacy (FL), Financial Pension Knowledge (PK) and Money 
Volume 3 Issue 8 (June 2021) PP. 41-59

DOI 10.35631/AIJBES.38003

Management (MANAGE) to its dependent variable which is Intention(I) to invest in a pension fund, the model is as follow:

$$
I=\alpha+\beta A T T+\beta S N+\beta P B C+\beta F L+\beta P K+\beta M M
$$

\section{Result and Discussion}

\section{Demographic Profile}

\section{Gender}

The result of the data collected which consist of 400 data of respondents show that the gender of the respondent is dominated by females which accounts for 69.5 per cent and male accounts for 30.5 per cent. In this case, the females are dominating because females are usually more willing to participate in the questionnaire than male.

\section{Age}

The result of the data collected from respondents shows that the age distribution of the respondent is dominated by college students ranged from 19-20 years old which account for 69.8 per cent caused by the respondents on those ages are already familiar with financial literacy rather than the younger and less busy than the older ages, while the other results are 17-18 years old which account for 5 per cent, 21-22 years old accounts for 24.3 per cent, and 23-24 years old account for 1 per cent of the total sample of the population.

\section{College Period}

The result of the data collected from respondents shows that the college period of the respondent mostly spread from 0 to 3 years which accounts for 85.5 per cent and the 14.5 per cent accounts for the respondents who spend more than 3 years in colleges. Those respondents are dominating because the earlier period students tend to have more free time thus, they are more willing to be exposed by new things.

\section{Faculty}

The result of the data collected from respondents shows that the college students mostly come from outside business and economic faculty and it accounts for 83.3 per cent, while the college students come from business and economic faculty accounts for 16.8 per cent. Students from non-business and economic faculty are dominating because there are only several universities in East Java who have business and economic faculty.

\section{Working Status}

The result of the data collected from respondents shows that the college students are mostly not having a job which accounts for 85.8 per cent, while students who are having a job both part time and fulltime account for 14.2 per cent. Students who are not having jobs are dominating because college students tend to focus on their study instead of being a worker.

\section{Validity and Reliability of Research Instrument}

The Pearson correlation will be valid if $r$ count $>r$ table. On this research, the validity and reliability test were measured using SPSS. Based on the Table 1, all the results of the Pearson correlation are more than .08215 as the $\mathrm{r}$ table of 400 respondents. Hence, all of the questions can be stated as valid. For the reliability test, the score of the Cronbach Alpha should be $>0.60$ 
Volume 3 Issue 8 (June 2021) PP. 41-59

DOI 10.35631/AIJBES.38003

as it can be categorized as good. All of the results of Cronbach Alpha are more than 0.60. Hence, all of the questions can be stated as reliable.

Table 1: Validity and Reliability

\begin{tabular}{|c|c|c|}
\hline & $\begin{array}{c}\text { Validity Test (Pearson } \\
\text { Correlation } \\
\end{array}$ & $\begin{array}{c}\text { Reliability Test (Cronbach } \\
\text { Alpha) }\end{array}$ \\
\hline ATT & & 0.897 \\
\hline Attitude 1 & 0.871 & \\
\hline Attitude 2 & 0.874 & \\
\hline Attitude 3 & 0.902 & \\
\hline Attitude 4 & 0.871 & \\
\hline $\mathrm{SN}$ & & 0.885 \\
\hline Subjective Norms 1 & 0.939 & \\
\hline Subjective Norms 2 & 0.930 & \\
\hline $\mathrm{PBC}$ & & 0.781 \\
\hline Perceived Behavioural & 0.662 & \\
\hline Control 1 & 1 & \\
\hline $\begin{array}{l}\text { Perceived Behavioural } \\
\text { Control } 2\end{array}$ & & \\
\hline
\end{tabular}

\section{Descriptive Statistics}

Table 2: Descriptive Statistic

\begin{tabular}{lrrrrr}
\hline & N & Minimum & Maximum & Mean & $\begin{array}{c}\text { Std. } \\
\text { Deviation }\end{array}$ \\
\hline Intention & 400 & 0 & 1 & .97 & .164 \\
Attitude1 & 400 & 1 & 7 & 6.22 & .990 \\
Attitude2 & 400 & 3 & 7 & 5.99 & 1.050 \\
Attitude3 & 400 & 2 & 7 & 6.06 & 1.024 \\
Attitude4 & 400 & 1 & 7 & 5.74 & 1.157 \\
SubjectiveNorms1 & 400 & 2 & 7 & 5.45 & 1.325 \\
SubjectiveNorms2 & 400 & 2 & 7 & 5.73 & 1.154 \\
PerceivedBehavioural1 & 400 & 1 & 7 & 5.13 & 1.325 \\
PerceivedBehavioural2 & 400 & 1 & 7 & 5.01 & 1.403 \\
FinancialLiteracy & 400 & 0 & 5 & 3.89 & 1.167 \\
PensionKnowledge & 400 & 0 & 4 & 2.91 & .927 \\
MoneyManagement & 400 & 0 & 1 & .86 & .347 \\
Valid N (listwise) & 400 & & & & \\
\hline
\end{tabular}

\section{Regression Analysis}

\section{Data Classification}

Based on the Table 3, the respondents who do not have the intention to invest in a pension fund (0) is 11 . Based on the prediction, 3 respondents do not have intention to invest in a pension fund $(0)$ and 8 respondents have intention to invest in a pension fund (1). Thus, it shows that Copyright $\odot$ GLOBAL ACADEMIC EXCELLENCE (M) SDN BHD - All rights reserved 
Volume 3 Issue 8 (June 2021) PP. 41-59

DOI 10.35631/AIJBES.38003

the true prediction will be 27.3 per cent. While the sample who have the intention to invest in a pension fund (1) is 389. Based on the prediction, 2 respondents do not have intention to invest in a pension fund and 387 respondents have intention to invest in a pension fund. Thus, it shows that the true prediction will be 99.5 per cent. Therefore, the overall percentage of the model is 97.5 per cent which can be interpreted that the accuracy of the model is 97.5 per cent.

Table 3: Classification Table

\begin{tabular}{|c|c|c|c|c|c|}
\hline & \multicolumn{2}{|c|}{ Observed } & \multicolumn{3}{|c|}{ Predicted } \\
\hline & & & \multicolumn{2}{|c|}{ DEPENDENT } & \multirow{2}{*}{$\begin{array}{c}\text { Percentage } \\
\text { Correct }\end{array}$} \\
\hline & & & 0 & 1 & \\
\hline \multirow{3}{*}{ Step 1} & DEPENDEN & 0 & 3 & 8 & 27.3 \\
\hline & $\mathrm{T}$ & 1 & 2 & 387 & 99.5 \\
\hline & \multicolumn{2}{|c|}{ Overall Percentage } & & & 97.5 \\
\hline
\end{tabular}

a. The cut value is, 500

\section{-2 Log Likelihood}

Based on the Table 4, the Iteration history Block 1 which explains the result when the independent variables were added to the model where:

$\mathrm{N} \quad=400$

Df $\quad=\mathrm{N}-$ the number of independent variables -1

$=400-6-1$

$=393$

Chi-Square $(0.05)=440.22$

In order to be categorized as FIT, the value of -2 Log Likelihood should be less than the value of the appropriate Chi-square. Based on the calculation by SPSS, the value of $-2 \log$ Likelihood (45.255) < Chi-Square value (440.22). Hence, it shows that the model added with independent variable is FIT with the data.

Table 4: -2 Log Likelihood

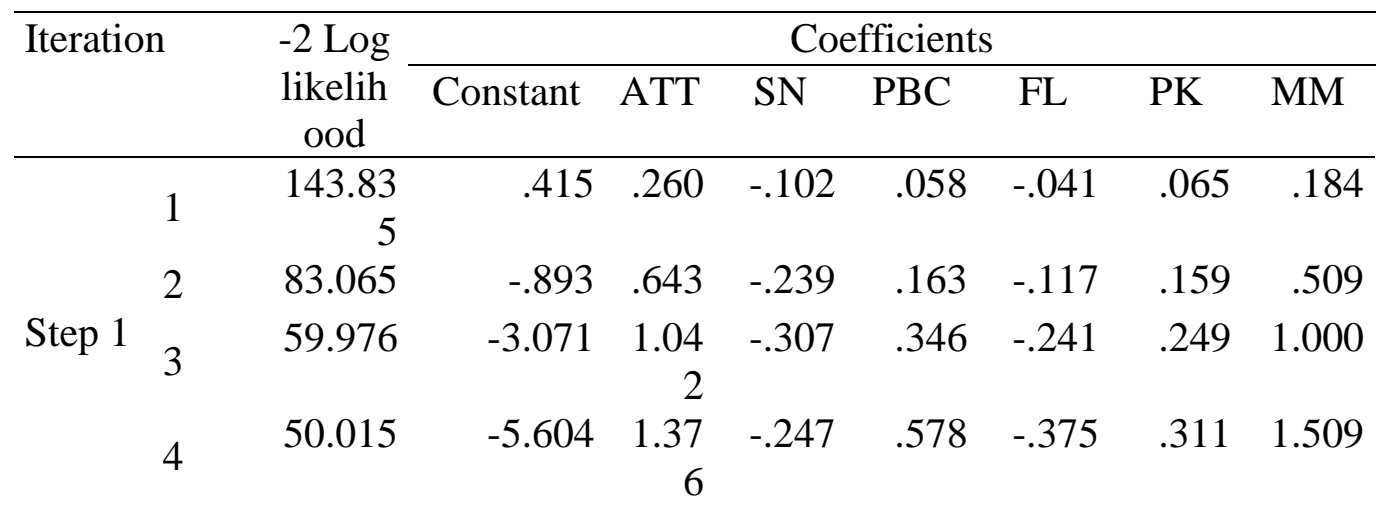


Volume 3 Issue 8 (June 2021) PP. 41-59 DOI 10.35631/AIJBES.38003

\begin{tabular}{|c|c|c|c|c|c|c|c|c|}
\hline 5 & 46.203 & -8.122 & $\begin{array}{r}1.68 \\
7\end{array}$ & -.154 & .807 & -.489 & .350 & 2.004 \\
\hline 6 & 45.298 & -9.913 & $\begin{array}{r}1.92 \\
8\end{array}$ & -.093 & .965 & -.570 & .373 & 2.375 \\
\hline 7 & 45.226 & -10.552 & $\begin{array}{r}2.02 \\
2\end{array}$ & -.076 & 1.022 & -.601 & .381 & 2.514 \\
\hline 8 & 45.225 & -10.615 & $\begin{array}{r}2.03 \\
1\end{array}$ & -.074 & 1.028 & -.605 & .382 & 2.529 \\
\hline 9 & 45.225 & -10.616 & 2.032 & -.074 & 1.028 & -.605 & .382 & 2.529 \\
\hline
\end{tabular}

a. Method: Enter

b. Constant is included in the model.

c. Initial -2 Log Likelihood: 100,753

d. Estimation terminated at iteration number 9 because parameter estimates changed by less than, 001 .

\section{Omnibus Test}

In order to be categorized as FIT, The Omnibus test should have the significance level $<0.05$. Based on the Table 5, The difference of -2 Log Likelihood between the initial model with the added variables model is 55.528 with the significance value of 0.000 which is less than 0.05 . Hence, the result shows that the addition of independent variables to the model gives a significant impact and the model can be stated as FIT.

Table 5: Omnibus test

\begin{tabular}{|c|c|c|c|c|}
\hline & & Chi-square & $\mathrm{df}$ & Sig. \\
\hline \multirow{3}{*}{ Step 1} & Step & 55.528 & 6 & .000 \\
\hline & Block & 55.528 & 6 & .000 \\
\hline & Model & 55.528 & 6 & .000 \\
\hline
\end{tabular}

\section{R-Square}

In order to test the ability of the independent variables in explaining the dependent variable, this research use Nagelkerke R-Square. Based on the Table 6, the value of the Nagelkerke RSquare is 0.582 or 58.2 per cent, which shows that the ability of independent variables in explaining the dependent variable is 58.2 per cent while the remaining 41.8 per cent will be explained by the factors outside the independent variables. 
Table 6: R-Square

\begin{tabular}{lccr}
\hline Step & -2 Log likelihood & $\begin{array}{c}\text { Cox \& Snell R } \\
\text { Square }\end{array}$ & \multicolumn{2}{c}{$\begin{array}{c}\text { Nagelkerke R } \\
\text { Square }\end{array}$} \\
\hline 1 & $45.225^{\mathrm{a}}$ & .130 & .582 \\
\hline
\end{tabular}

\section{Hosmer and Lemeshow Test}

In order to be categorized as FIT, the Hosmer and Lemeshow test should have a significance level $>0.05$ and the Chi-Square $>0.05$. Based on the Table 7, the significance level is 1 which is more than 0.05 and the Chi-Square is 0.408 which is also more than 0.05 . Hence, the model can be categorized as FIT.

Table 7: Hosmer and Lemeshow

\begin{tabular}{lrrr}
\hline Step & Chi-square & df & \multicolumn{2}{c}{ Sig. } \\
\hline 1 & .408 & 8 & 1.000 \\
\hline
\end{tabular}

\section{Regression Result}

Table 8: Regression Result

\begin{tabular}{rlrrrrrrrr}
\hline & & B & S.E. & Wald & df & Sig. & Exp(B) & \multicolumn{2}{c}{$95 \%$ C.I.for EXP(B) } \\
Lower & \multicolumn{1}{c}{ Upper } \\
\hline & & & & & & & & \\
& ATT & 2.032 & .635 & 10.226 & 1 & .001 & 7.626 & 2.196 & 26.489 \\
Step 1 & SN & -.074 & .458 & .026 & 1 & .872 & .929 & .378 & 2.279 \\
& PBC & 1.028 & .446 & 5.316 & 1 & .021 & 2.795 & 1.167 & 6.695 \\
& FL & -.605 & .421 & 2.061 & 1 & .151 & .546 & .239 & 1.247 \\
& PK & .382 & .404 & .895 & 1 & .344 & 1.465 & .664 & 3.232 \\
& MM & 2.529 & 1.023 & 6.106 & 1 & .013 & 12.537 & 1.687 & 93.162 \\
& Constant & -10.616 & 3.759 & 7.978 & 1 & .005 & .000 & & \\
\hline
\end{tabular}

a. Variable(s) entered on step 1: ATT, SN, PBC, FL, PK, MM.

Based on the regression result on the Table 8 , the research model is as follow:

$$
I=2.032 A T T-0.074 S N+1.028 P B C-0.605 F L+0.382 P K+2.529 M M
$$

\section{Research Finding}

\section{Attitude And Intention To Invest In A Pension Fund}

Based on the result, it is known that the Sig. value of attitude is 0.001 which is less than 0.05 . Therefore, attitude has a significant influence on college student intention to invest in a pension fund. By looking at the regression result, we may justify that in the context of East Java college students, their settled way of thinking about the importance of pension fund is positive and potentially influence their further intention to invest in a pension fund. This finding is parallel 
Volume 3 Issue 8 (June 2021) PP. 41-59 DOI 10.35631/AIJBES.38003

to the study of Bongini and Cucinelli (2019) which states that there is a positive relationship regarding a saving decision (attitude) as the driver of decision for a college student to invest in a pension fund. From the study made by Davis and Hustvedt (2012) also assumes that an individual attitude towards a certain behaviour positively influence the intention to save for retirement.

\section{Subjective Norms And Intention To Invest In A Pension Fund}

Based on the result, it is known that the Sig. value of attitude is 0.872 which is more than 0.05 . Therefore, Subjective Norms does not have significant influence on college student intention to invest in a pension fund. By looking at the regression result, we may justify that in the context of East Java college students, the power of family and relatives influence do not have a significant impact on their intention to invest in a pension fund. This finding is parallel to the study by Rickwood et al (2017) which states that subjective knowledge do not significantly influence behavioural intention.

\section{Perceived Behavioural Control And Intention To Invest In A Pension Fund}

Based on the result, it is known that the Sig. value of perceived behavioural control is 0.021 which is less than 0.05. Therefore, Perceived Behavioural Control has a significant influence on college student intention to invest in a pension fund. By looking at the regression result, we may justify that in the context of East Java college students, their capability of choosing pension fund have significant impact on their intention to invest in a pension fund as they found that the access was not that easy to reach. This finding is parallel to the study by Nosi et al (2017) which states that PBC has a relevancy on the intention to buy long term investment which in this case is pension fund. Further than that, Davis and Hustvedt (2012) also stated in their investigation that perceived behavioural control could predict the saving for retirement.

\section{Financial Literacy and Intention to invest in a pension fund}

Based on the result, it is known that the Sig. value of attitude is 0.151 which is more than 0.05 . Therefore, Financial Literacy does not have a significant influence on college student intention to invest in a pension fund. By looking at the regression result, we may justify that in the context of East Java college students which most of the sample are willingly to invest in a pension fund by no means supported by the higher level of financial literacy. Where they could have the intention to invest without being fully understood the deeper meaning of the context by which means the calculation of time value of money, inflation and interest. The respondents tend to reject and feel that anything related to calculation is beyond their ability. This finding is parallel to the study by Widyastuti, Suhud and Sumiati (2016) which states that financial literacy is not significant to savings intention.

\section{Pension Knowledge and Intention to invest in a pension fund}

Based on the result, it is known that the Sig. value of pension knowledge 0.344 which is more than 0.05. Therefore, Pension Knowledge does not have a significant influence on college student intention to invest in a pension fund. By looking at the regression result, we may justify that in the context of East Java college students, their pension planning, retirement salary and their knowledge regarding supplementary fund do not have a significant impact on their intention to invest in a pension fund, as they thought that retirement period is still long enough to consider by now. This finding is parallel to the study proposed by Hati, Wibowo and Safira (2020) which states that product knowledge does not have a significant influence on intention to invest.

Copyright $\odot$ GLOBAL ACADEMIC EXCELLENCE (M) SDN BHD - All rights reserved 


\section{Money Management And Intention To Invest In A Pension Fund}

Based on the result, it is known that the Sig. value of money management is 0.013 which is less than 0.05. Therefore, Money Management has a significant influence on college student intention to invest in a pension fund. By looking at the regression result, we may justify that in the context of East Java college students, which most of them are having direct control over their monthly income will also influence their intention to invest in a pension fund. This finding is parallel to the study proposed by Bongini and Cucinelli (2019) which states that the behaviour of managing pocket money for college student will have a significant influence to their intention to invest, as well as it will have a long term impact in terms of financial planning dan its decision making.

\section{Conclusion}

The objective of this research is to define the factors that significantly affect college student's intention to invest in a pension fund. The issue of retirement has been raised as people become more aware about their welfare after pension. People tend to get minimum incomes in the retirement period because of the absence of monthly salary or getting a small amount of pension benefit, moreover there are several people who surrender their life to their family. As a sufficient standard of living is subjective, to establish an adequate standard of living after retirement, people have to plan and control their lifestyle since they are still generating money. Thus, by making well prepared retirement planning, it will stimulate people to control lifestyle and prepare to live independently after being retired. Having a positive attitude towards retirement planning is needed from the earlier age which can be started intensively since people are pursuing college. Students who come from Diplomas and Undergraduate are dominated by people who are not working yet, thus they still have enough time to enrich their knowledge regarding retirement plans. So, as they become a worker, they will be clear about preparing funds both for daily life and the retirement period. Students from those degrees are also in the productive age to be able to plan and execute their plan appropriately.

Our result indicates that the intention from the subjects to invest in a pension fund is own the majority of the respondents which count for 97.25 per cent over the population, it shows that the college students in East Java have a very high intention to invest in a pension fund. Based on the regression result carried out using SPSS, Money Management and two of the TPB factors which are Attitude and Perceived Behavioural Control are significantly influenced college students' intention to invest in a pension fund. Based on coefficient differentiation result, the value of the Nagelkerke R-Square is 0.582 or 58.2 per cent, which shows that the ability of TPB factors, Financial Literacy, Pension Knowledge and Money Management in explaining the Intention to invest in a pension fund is 58.2 per cent while the remaining 41.8 per cent will be explained by the factors outside this study. From the significant level of Attitude, Perceived Behavioural Control and Money Management it can be concluded that the intention to invest in a pension fund is more influenced by the behaviour that are in direct contact with the subject.

\section{References}

[BPS] Badan Pusat Statistik (2019) 'Indeks Pembangunan Manusia (IPM) Tahun 2018', (32), pp. 1-9.

Abd Samad, S. and Mansor, N. (2013) 'Population ageing and social protection in malaysia', Malaysian Journal of Economic Studies. 
Volume 3 Issue 8 (June 2021) PP. 41-59 DOI 10.35631/AIJBES.38003

Afandi, T. (2017) 'Bonus Demografi 2030-2040: Strategi Indonesia Terkait Ketenagakerjaan Dan Pendidikan', Kementerian Perencanaan Pembangunan Nasional, pp. 1-2.

Agnew, J., Bateman, H. and Thorp, S. (2013) 'Financial Literacy and Retirement Planning in Australia', Numeracy. doi: 10.5038/1936-4660.6.2.7.

Ajzen, I. (1991) 'The theory of planned behavior', Organizational Behavior and Human Decision Processes. doi: 10.1016/0749-5978(91)90020-T.

Ajzen, I. (2002) 'Constructing a TpB Questionnaire: Conceptual and Methodological Considerations', Time.

Blumberg, B. F., Cooper, D. R., \& Schindler, P. S. (2014) Business research methods, Business Research Methods.

Boisclair, D., Lusardi, A. and Michaud, P. C. (2017) 'Financial literacy and retirement planning in Canada', Journal of Pension Economics and Finance. doi: $10.1017 /$ S 1474747215000311.

Bongini, P. and Cucinelli, D. (2019) 'University students and retirement planning: never too early', International Journal of Bank Marketing, 37(3), pp. 775-797. doi: 10.1108/IJBM-03-2018-0066.

Boon, T. H., Yee, H. S. and Ting, H. W. (2011) 'Financial literacy and personal financial planning in Klang Valley, Malaysia', International Journal of Economics and Management.

Bucciol, A. and Veronesi, M. (2014) 'Teaching children to save: What is the best strategy for lifetime savings?', Journal of Economic Psychology. doi: 10.1016/j.joep.2014.07.003.

Castro-Gonzales, K. C. (2014) 'Financial Literacy and Retirement Planning: Evidence from Puerto Rico', Global Journal of Business Research.

Chan, S. and Stevens, A. H. (2008) 'What you don't know can't help you: Pension knowledge and retirement decision-making', Review of Economics and Statistics. doi: 10.1162/rest.90.2.253.

Crossan, D., Feslier, D. and Hurnard, R. (2011) 'Financial literacy and retirement planning in New Zealand', Journal of Pension Economics and Finance. doi: $10.1017 / \mathrm{S} 1474747211000515$.

Davis, K. and Hustvedt, G. (2012) 'It's a Matter of Control: Saving for Retirement', International Review of Social Sciences and Humanities.

Dikti, M. (2018) 'Indonesia Higher Education Statistical Year Book 2018', Chemistry - A European Journal, 15(21), pp. 1-7. Available at: https://pddikti.ristekdikti.go.id/asset/data/publikasi/Statistik Pendidikan Tinggi Indonesia 2018.pdf.

Fornero, E. (2015) 'EconomiccFinancial Literacy and (Sustainable) Pension Reforms: Why the Former is a Key Ingredient for the Latter', SSRN Electronic Journal. doi: $10.2139 / \mathrm{ssrn} .2665089$.

Furnham, A. (1999) 'Economic socialization: A study of adults' perceptions and uses of allowances (pocket money) to educate children', British Journal of Developmental Psychology. doi: 10.1348/026151099165492.

Furnham, A. and Kirkcaldy, B. (2000) 'Economic Socialization: German Parents' Perceptions and Implementation of Allowances to Educate Children', European Psychologist. doi: 10.1027//1016-9040.5.3.202.

Habib, S. (2007) Counting on the nest egg. Available at: http://thestar.com.my/news/story.asp?file=/2007/5/27/nation/17754089\&sec=nation. 
Volume 3 Issue 8 (June 2021) PP. 41-59 DOI 10.35631/AIJBES.38003

Hassan, K. H. et al. (2016) 'Retirement Planning Behaviour of Working Individuals and Legal Proposition for New Pension System in Malaysia', Journal of Politics and Law. doi: 10.5539/jpl.v9n4p43.

Hati, S. R. H., Wibowo, S. S. and Safira, A. (2020) 'The antecedents of Muslim customers' intention to invest in an Islamic bank's term deposits: evidence from a Muslim majority country', Journal of Islamic Marketing. doi: 10.1108/JIMA-01-2020-0007.

Hayuningtyas Pramesti Dewi, SE., Ak., M.Ak., C. and Lestari, F. D. (2016) 'AKUNTANSI DANA PENSIUN PROGRAM MANFAAT PASTI TERHADAP LAPORAN KEUANGAN STUDI PADA DANA PENSIUN BANK INDONESIA (DAPENBI)'. Available at: https://www.researchgate.net/publication/333144336_AKUNTANSI_DANA_PENSI UN_PROGRAM_MANFAAT_PASTI_TERHADAP_LAPORAN_KEUANGAN_ST UDI_PADA_DANA_PENSIUN_BANK_INDONESIA_DAPENBI.

Hershey, D. A. and Mowen, J. C. (2000) 'Psychological determinants of financial preparedness for retirement', Gerontologist. doi: 10.1093/geront/40.6.687.

Ibrahim, D., Isa, Z. M. and Ali, N. (2012) 'Malaysian Savings Behavior towards Retirement Planning', IInternational Conference on Economics Marketing and Management. doi: $10.1159 / 000343971$.

Katadata (2020) 'Melihat Skema Perubahan Aturan Dana Pensiun, Termasuk untuk PNS'. Available at: https://katadata.co.id/sortatobing/berita/5f153a342aed2/melihat-skemaperubahan-aturan-dana-pensiun-termasuk-untuk-pns.

Kirkcaldy, B., Furnham, A. and Martin, T. (2003) 'Parental attitudes towards pocket money, trait competitiveness and occupational stress', Journal of Managerial Psychology. doi: 10.1108/02683940310473073.

Klapper, L. F. and Panos, G. A. (2012) 'Financial Literacy and Retirement Planning in View of a Growing Youth Demographic: The Russian Case', SSRN Electronic Journal. doi: $10.2139 /$ ssrn.1809723.

Kontan, A. (2017) 'Dana pensiun dan generasi milenial'. Available at: https://analisis.kontan.co.id/news/dana-pensiun-dan-generasi-milenial?page=all.

Landerretche, O. M. and Martínez, C. (2013) 'Voluntary savings, financial behavior, and pension finance literacy: Evidence from Chile', Journal of Pension Economics and Finance. doi: 10.1017/S1474747212000340.

Lewis, A. and Scott, A. J. (2000) 'The Economic Awareness, Knowledge and Pocket Money Practices of a Sample of UK Adolescents: A Study of Economic Socialisation and Economic Psychology', Citizenship, Social and Economics Education. doi: 10.2304/csee.2000.4.1.34.

Lusardi, A. and Mitchell, O. S. (2007) 'Baby Boomer retirement security: The roles of planning, financial literacy, and housing wealth', Journal of Monetary Economics. doi: 10.1016/j.jmoneco.2006.12.001.

Lusardi, A. and Mitchell, O. S. (2009) How ordinary consumers make complex economic decisions, financial literacy and retirement readiness.

Lusardi, A. and Mitchell, O. S. (2011) 'Financial literacy and retirement planning in the United States', Journal of Pension Economics and Finance, 10(4), pp. 509-525. doi: 10.1017/S147474721100045X.

Lusardi, A. and Mitchelli, O. (2007) 'Financial literacy and retirement preparedness: Evidence and implications for financial education', Business Economics. doi: 10.2145/20070104. 
Volume 3 Issue 8 (June 2021) PP. 41-59 DOI 10.35631/AIJBES.38003

Merdeka (2020) OJK Sasar Mahasiswa Tingkatkan Inklusi dan Literasi Keuangan Indonesia. Available at: https://www.merdeka.com/uang/ojk-sasar-mahasiswa-tingkatkan-inklusidan-literasi-keuangan-indonesia.html.

Mohidin, R. et al. (2013) 'Revisiting the Relationship Between Attitudes and Retirement Planning Behavior : A Study on Personal Financial Planning', International Journal of Multidisciplinary Thought.

Moorthy, K., Chelliah, T.D., Sien, C.S., Leon, L C., Kai, N.Z., Rhu, W.C. and Teng, W. Y. (2012) 'A study on the retirement planning behaviour of working individuals in Malaysia', International Journal of Academic Research in Economic and Management Sciences, 1(2), pp. 54-72.

Ngumar, S. (2016) 'Akuntansi Dana Pensiun Di Indonesia', EKUITAS (Jurnal Ekonomi dan Keuangan), 1(3), p. 115. doi: 10.24034/j25485024.y1997.v1.i3.1853.

Nosi, C. et al. (2017) 'Securing retirement at a young age. exploring the intention to buy longevity annuities through an extended version of the Theory of Planned Behavior', Sustainability (Switzerland). doi: 10.3390/su9061069.

OECD (2016) 'OECD Pensions Outlook' . Available at: https://www.oecd-ilibrary.org/financeand-investment/oecd-pensions-outlook-2016_pens_outlook-2016-en.

OJK-RI (2017) 'Strategi Nasional Literasi Keuangan Indonesia (Revisit 2017)', Otoritas Jasa Keuangan, pp. 1-99. Available at: https://www.ojk.go.id/id/berita-dankegiatan/publikasi/Pages/Strategi-Nasional-Literasi-Keuangan-Indonesia-(Revisit2017)-.aspx

OJK (2019) buku 6 Program Pensiun seri literasi keuangan perguruan tinggi. Available at: https://sikapiuangmu.ojk.go.id/FrontEnd/LiterasiPerguruanTinggi/assets/pdf/Buku 6 Program Pensiun.pdf.

Otoritas Jasa Keuangan (2019) 'Statistik Dana Pensiun’, p. 61.

Ricci, O. and Caratelli, M. (2017) 'Financial literacy, trust and retirement planning', Journal of Pension Economics and Finance. doi: 10.1017/S1474747215000177.

Rickwood, C. M. et al. (2017) 'Customer Intention To Save for Retirement Using a Professional Financial Services Planner', Financial Planning Research Journal.

van Rooij, M. C. J., Lusardi, A. and Alessie, R. J. M. (2012) 'Financial Literacy, Retirement Planning and Household Wealth', Economic Journal. doi: 10.1111/j.14680297.2012.02501.x.

Sekita, S. (2011) 'Financial literacy and retirement planning in Japan', Journal of Pension Economics and Finance. doi: 10.1017/S1474747211000527.

Shafee, N. B. (2018) 'Future Retirement Planning Among Malacca Youth', 10(3), pp. 372381.

Šimundić, A. M. (2008) 'Interval pouzdanosti', Biochemia Medica.

Subha, M. V. and Shanmugha, P. P. (2014) 'The Emerging Role of Financial Literacy Financial Planning', IJISET -International Journal of Innovative Science, Engineering \& Technology.

Tempo.Co (2018) 'Pentingnya Generasi Milenial Investasi untuk Pensiun'. Available at: https://gaya.tempo.co/read/1145082/pentingnya-generasi-milenial-investasi-untukpensiun/full\&view=ok.

UNAIR News (2019) OJK Teken Kerja Sama dengan UNAIR Edukasi Masyarakat Soal Jasa Keuangan. Available at: http://news.unair.ac.id/2019/11/05/ojk-teken-kerja-samadengan-unair-edukasi-masyarakat-soal-jasa-keuangan/. 
Volume 3 Issue 8 (June 2021) PP. 41-59 DOI 10.35631/AIJBES.38003

Widyastuti, U., Suhud, U. and Sumiati, A. (2016) 'The Impact of Financial Literacy on Student Teachers' Saving Intention and Saving Behaviour', Mediterranean Journal of Social Sciences. doi: 10.5901/mjss.2016.v7n6p41. 